\title{
The ubiquitin ligase Rsp5 is required for ribosome stability in Saccharomyces cerevisiae
}

\author{
NATALIA SHCHERBIK and DIMITRI G. PESTOV ${ }^{\mathbf{1}}$ \\ Department of Cell Biology, University of Medicine and Dentistry of New Jersey, Stratford, New Jersey 08084, USA
}

\begin{abstract}
Rsp5p is a conserved HECT-domain ubiquitin ligase with diverse roles in cellular physiology. Here we report a previously unknown role of $\mathrm{Rsp} 5 \mathrm{p}$ in facilitating the stability of the cytoplasmic ribosome pool in budding yeast. Yeast strains carrying temperature-sensitive mutations in RSP5 showed a progressive decline in levels of $18 \mathrm{~S}$ and $25 \mathrm{~S}$ rRAs and accumulation of rRNA decay fragments when cells grown in rich medium were shifted to restrictive temperature. This was accompanied by a decreased number of translating ribosomes and the appearance of ribosomal subunits with an abnormally low sedimentation rate in polysome analysis. Abrogating Rsp5p function affected stability of other tested noncoding RNA species (tRNA and snoRNA), but to a lower extent than that of rRNA, and also inhibited processing of rRNA and tRNA precursors, in agreement with previous studies. The breakdown of cellular ribosomes was not affected by deletion of key genes involved in autophagy, previously implicated in ribosome turnover upon starvation. Our results suggest that functional Rsp5p is required to maintain the integrity of cytoplasmic ribosomes under rich nutrient conditions.
\end{abstract}

Keywords: rRNA; E3 ubiquitin ligase; RNA decay

\section{INTRODUCTION}

Cells up-regulate their protein biosynthetic capacity in response to growth stimuli by increasing synthesis of new ribosomes (Warner 1999; Jorgensen et al. 2004). Mature ribosomes are normally stable under optimal growth conditions, as demonstrated by measurements of the rRNA synthesis and decay rates in a variety of prokaryotic and eukaryotic organisms (Weber 1972; Yuan and Shen 1975; Kief and Warner 1981; Deutscher 2003). Suboptimal nutrient conditions, in contrast, have been observed to promote degradation of a fraction of ribosomes (Johnston et al. 1977; Ju and Warner 1994; Deutscher 2003; Zundel et al. 2009; Basturea et al. 2011), although the mechanisms underlying this phenomenon are still poorly defined. One type of ribosome turnover induced by starvation in budding yeast was proposed to depend on a specialized type of autophagy, termed ribophagy (Kraft et al. 2008). A notable exception to the normally high stability of mature ribosomes in growing yeast cells is the selective degradation of defective ribosomes that are rendered nonfunctional by

\footnotetext{
${ }^{1}$ Corresponding author.

E-mail pestovdg@umdnj.edu.

Article published online ahead of print. Article and publication date are at http://www.rnajournal.org/cgi/doi/10.1261/rna.2615311.
}

mutations in their rRNA (LaRiviere et al. 2006; Cole et al. 2009; Fujii et al. 2009). Ribosomes damaged by oxidative stress also undergo accelerated degradation (Mroczek and Kufel 2008). Evidence suggests that defects in ribosome surveillance may contribute to the pathogenesis of a number of human diseases (Lafontaine 2010).

One intriguing aspect of ribosome stability in a cell is the presence of a multitude of RNases in the intracellular environment. Because the backbone of the ribosome structure is formed by RNA, ribosomes are potentially susceptible to damage by cellular RNases, yet normally, rRNA in ribosomes appears to be immune to their activities. It seems logical to assume that some structural features of ribosomes or tight control over RNase activities in the cell (or a combination of these factors) contribute to the high ribosome stability. The actual mechanisms that keep ribosomes secure from a nuclease attack, however, are not well understood, and neither are the conditions that could make ribosomes lose their protected status.

Here we report the unexpected finding that ribosome stability in growing cells of $S$. cerevisiae depends on the functioning ubiquitin ligase Rsp5p. Rsp5p is an essential HECT domain-containing E3 ubiquitin ligase (Huibregtse et al. 1995) that modifies a wide range of targets with both monoubiquitin and polyubiquitin chains, preferably linking ubiquitin through the K63 residue (Kaliszewski and 
Żołądek 2008; Rotin and Kumar 2009). This type of posttranslational modification typically serves nonproteolytic functions (Hicke 2001; Weissman 2001; Chen and Sun 2009), in contrast to K48-linked polyubiquitin chains that usually target substrates for proteasome degradation (Hochstrasser 1996; Roos-Mattjus and Sistonen 2004; Thompson et al. 2008). Rsp5p has been previously implicated in a range of cellular processes: sorting, trafficking, and endocytosis of plasma membrane proteins, biosynthesis of unsaturated fatty acids, actin cytoskeleton maintenance, mitochondrial inheritance, and others (for review, see Belgareh-Touzé et al. 2008; Kaliszewski and Żołądek 2008; Rotin and Kumar 2009). Several links between Rsp5p and the translation machinery have been reported, including Rsp5p involvement in the maturation and nuclear export of rRNA, mRNA, and tRNA (Neumann et al. 2003; Rodriguez et al. 2003; Haitani and Takagi 2008) and modulating accuracy of translation (Kwapisz et al. 2005). Despite intense study, the importance of Rsp5p for maintaining ribosome stability has not been previously recognized. As the data presented below demonstrate, lack of Rsp5p function can lead to extensive nucleolytic degradation of rRNA, resulting in a loss of cytoplasmic ribosomes.

\section{RESULTS AND DISCUSSION}

\section{Degradation of rRNA in rsp5 mutants}

Previous studies of Rsp5p showed a significant drop in protein synthesis rates in temperature-sensitive $(t s) r s p 5 \mathrm{mu}-$ tants at nonpermissive temperatures (Krsmanović and Kölling 2004; Kwapisz et al. 2005), which was attributed largely to changes in translational control. During our analysis of the strain MK15 harboring the ts allele rsp5-19 (Kaliszewski et al. 2006), we noticed a dramatic decrease in cellular rRNA levels when cells grown in the YPDA medium at a permissive temperature $\left(25^{\circ} \mathrm{C}\right)$ were shifted to restrictive $\left(37^{\circ} \mathrm{C}\right)$ temperature (Fig. 1A). Hybridization analysis of rRNA in rsp5-19 cells transferred to $37^{\circ} \mathrm{C}$ revealed a pronounced smear of rRNA-derived decay products as well as accumulation of a distinct large 25S rRNA fragment (Fig. 1A,B, asterisk). Destabilization of rRNA was not a general effect of elevated temperature or cell cycle arrest, as rRNA levels remained largely unchanged in a variety of other $t s$ strains tested (Fig. 1A, $c d c 48-3$ is shown as an example; Supplemental Fig. S1). rRNA was also stable at $37^{\circ} \mathrm{C}$ in the parental to $r s p 5-19$ strain $\mathrm{MK} 1$, in which the
A

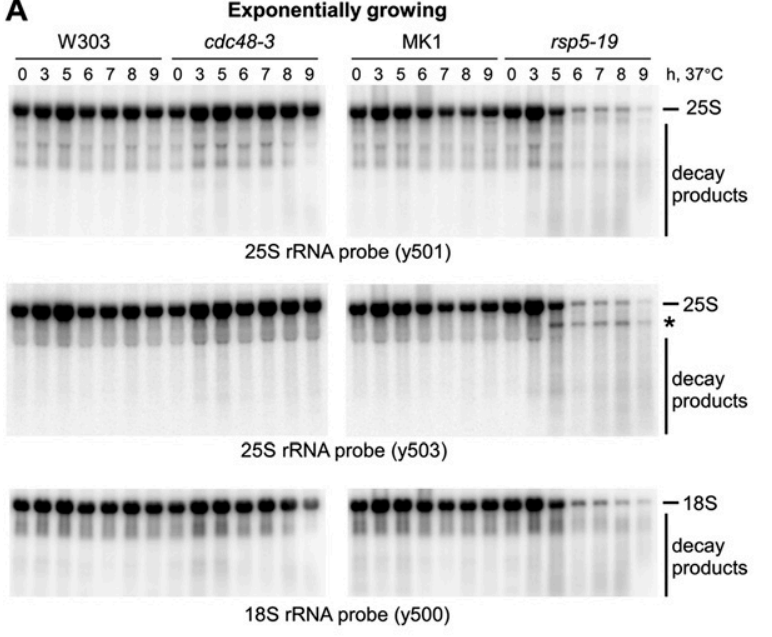

B

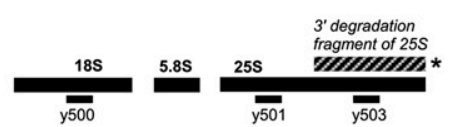

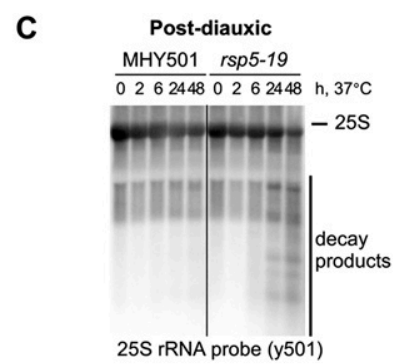

D

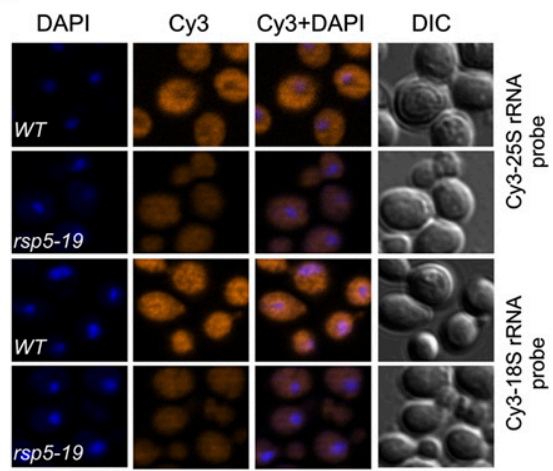

FIGURE 1. rRNA levels decrease in $r s p 5-19$ cells shifted to $37^{\circ} \mathrm{C}$. (A) Cells harboring $t s$ mutations $c d c 48-3$ and $r s p 5-19$ and the isogenic wild-type strains (W303 and MK1) were grown in YPDA at $25^{\circ} \mathrm{C}$ to mid-log phase and shifted to $37^{\circ} \mathrm{C}$. Cells were collected at the indicated time points, counted, and RNA was extracted from $10^{7}$ cells and analyzed by Northern hybridizations with the indicated probes against $25 \mathrm{~S}$ and $18 \mathrm{~S}$ rRNAs. Wild-type cell cultures were periodically diluted with fresh medium to maintain $\mathrm{OD}_{600} 0.3-0.5$ throughout the time course. Asterisk indicates the position of a 3' degradation fragment of $25 \mathrm{~S}$ rRNA. (B) Schematic representation of the hybridization sites for oligonucleotide probes against $18 \mathrm{~S}$ and $25 \mathrm{~S}$ rRNAs. The striped bar marked with an asterisk depicts the large degradation fragment of $25 \mathrm{~S}$ rRNA detected in $r s p 5$ cells. (C) Delayed induction of rRNA degradation when $r s p 5-19$ cells in the post-diauxic phase of growth $\left(24 \mathrm{~h}\right.$ in YPDA) were shifted to $37^{\circ} \mathrm{C}$. $(D)$ rRNA in MK1 (WT) and rsp5-19 cells analyzed by fluorescent in situ hybridization. Mid-log cultures in YPDA were shifted from $25^{\circ} \mathrm{C}$ to $37^{\circ} \mathrm{C}$ for $5 \mathrm{~h}$. rRNA was detected in fixed cells with Cy3-modified oligonucleotides complementary to $25 \mathrm{~S}$ and $18 \mathrm{~S}$ rRNAs. The same exposure (102 msec for the $25 \mathrm{~S}$ probe and $500 \mathrm{msec}$ for the $18 \mathrm{~S}$ probe) was used for WT and $r s p 5-19$ cells. Also shown are the DIC view and DAPI staining of nuclear DNA in the same fields. 
cellular ribosome content actually increased transiently between 3 and $5 \mathrm{~h}$ after temperature shift (Fig. 1A). The onset of rRNA degradation caused by rsp5 mutations was delayed in stationary phase or under nutrient-limiting conditions (Fig. 1C; data not shown), suggesting that Rsp5p function might be especially important for ribosome stability in rapidly growing yeast cells.

To verify the reduction of rRNA levels in $r s p 5-19$ cells by an alternative method, we performed fluorescent in situ hybridization of $25 \mathrm{~S}$ and $18 \mathrm{~S}$ rRNA using Cy3labeled oligonucleotide probes. Consistent with the hybridization analysis of rRNA isolated from cells, the diffuse cytoplasmic staining of rRNA became uniformly weaker in rsp5-19 cells as compared with wild type after a 5-h incubation at $37^{\circ} \mathrm{C}$ (Fig. 1D). This result indicates a decrease in the total level of probe targets (i.e., mature rRNA and rRNA-derived degradation fragments). Microscopic observations did not reveal any gross changes in cell integrity that could potentially account for the rRNA losses.

\section{Different mutations in RSP5 can cause destabilization of rRNA}

The $r s p 5-19$ mutation in the MK15 strain used in the above experiments affects a conserved proline residue (P418L) within the substrate-binding domain WW3 of Rsp5p, conferring a ts phenotype (Kaliszewski et al. 2006). To confirm that the observed decay of rRNA in rsp5-19 cells was not due to unrelated $t s$ mutations present in the MK15 strain, we first introduced the rsp5-19 allele into a different genetic background (INVSc). Shifting this newly generated strain to $37^{\circ} \mathrm{C}$ resulted in an rRNA degradation pattern similar to that in MK15 cells (Fig. 2A).

We next asked whether other mutations in RSP5 that functionally inactivate the encoded protein could lead to rRNA degradation. We examined rRNA levels by Northern hybridizations in strains with two previously characterized ts alleles: rsp5-3 containing three mutations, T104A, E673G, and Q716P (Neumann et al. 2003), and rsp5-1 containing a single L733S substitution in the catalytic HECT domain (Wang et al. 1999). We found that these cells exhibited a similar rRNA degradation phenotype at the nonpermissive temperature (Fig. 2A; Fig. 2B, top). The rRNA degradation was not observed in the isogenic wild-type strains at $37^{\circ} \mathrm{C}$ (Supplemental Fig. S2). Finally, expression of a wild-type Rsp5p from a plasmid in rsp5-19 cells was sufficient to protect ribosomes from degradation (Fig. 2C). Based on these results, we conclude that the ubiquitin ligase Rsp5p plays a previously unknown role in maintaining rRNA stability in yeast cells.

\section{Degradation of different types of noncoding RNAs in rsp5-19 cells}

Previous studies indicated that abrogating Rsp5p function inhibits production of new ribosomal subunits and their export from the nucleus (Neumann et al. 2003). Northern hybridization with a probe recognizing the internal transcribed spacer 2 region (ITS2) in pre-rRNA confirmed a strong accumulation of the nuclear $35 \mathrm{~S}$ pre-rRNA transcript and reduced levels of the $27 \mathrm{~S}$ and $7 \mathrm{~S}$ pre-rRNAs in $r s p 5-1$ and other $r s p 5^{t s}$ strains at the nonpermissive temperature (Fig. 2B, bottom; data not shown), consistent with impaired ribosome maturation. Notably, no smear of decay products was visible in hybridizations with the pre-rRNA-specific probe, in contrast to mature 25S rRNA (Fig. 2B; cf. top and bottom panels). The lack of prerRNA degradation fragments is not surprising, since the majority of defective intermediates in ribosome assembly are rapidly eliminated by active RNA surveillance systems in the nucleus (Dez et al. 2006; Vanacova and Stefl 2007).

Because ribosome biogenesis was affected in rsp5 mutants, we considered the possibility that the diminished 
rRNA levels might simply reflect decay of newly synthesized ribosomes. To verify that pre-existing ribosomes can also be targets for decay, we pulse-labeled rRNA in cells with $\left[{ }^{3} \mathrm{H}\right]$ uracil, transferred these cells into the YPDA medium, incubated them for an additional 5-10 $\mathrm{h}$ at $37^{\circ} \mathrm{C}$, and then examined $\left[{ }^{3} \mathrm{H}\right]$-labeled $25 \mathrm{~S}$ and $18 \mathrm{~S}$ rRNAs. By this type of analysis, we are only assessing levels of mature ribosomes, because labeled rRNA precursors are completely processed into mature rRNAs within 10-20 min after the pulse (Kos and Tollervey 2010). As shown in Figure 3A, the signal of the prelabeled $25 \mathrm{~S}$ and $18 \mathrm{~S}$ rRNAs underwent a significant decline between 5 and $10 \mathrm{~h}$ in the rsp5-19 cells at $37^{\circ} \mathrm{C}$, whereas no such effect was observed in the control $c d c 48$-3 strain that was similarly arrested in growth at this temperature. In $r s p 5-19$ cells, there was also a clearly visible accumulation of an aberrant RNA (Fig. $3 \mathrm{~A}$, asterisk) that matched the size of the $25 \mathrm{~S}$ degradation product detected in hybridizations (Fig. 1A,B, asterisk). We thus conclude that the reduction of rRNA levels in rsp5-19 cells indeed involves degradation of pre-existing mature ribosomes.

We next compared the decay rate of rRNA in rsp5-19 cells with other types of noncoding RNAs. Northern hybridizations with different probes were performed on the same membrane to avoid loading variations (Fig. 3B). PhosphorImager quantification (Fig. 3C) showed that 25S and 18S rRNA levels in rsp5-19 cells decreased $\sim 40$-fold over the period of $10 \mathrm{~h}$ at $37^{\circ} \mathrm{C}$, compared with a three- to fivefold reduction in tRNA ${ }^{\text {Leu }}$ and U3 snoRNA levels. Unlike mature tRNA ${ }^{\text {Leu }}$, tRNA ${ }^{\text {Leu }}$ precursors accumulated in rsp5-19 cells (Fig. 3B, arrow). The latter result is consistent with a tRNA maturation defect, which was also observed in another RSP5 mutant, rsp5-3 (Neumann et al. 2003). There were no significant changes in any of these RNAs at $37^{\circ} \mathrm{C}$ in the control $c d c 48-3$ strain (Fig. 3B,C). These data indicate that while abrogating Rsp5p function affects multiple RNAs, mature rRNAs appear to be especially vulnerable to degradation and are lost from cells at a much greater rate than other stable RNA types.
A

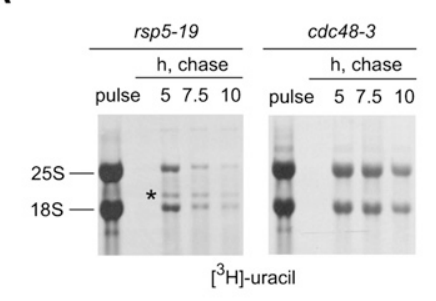

B

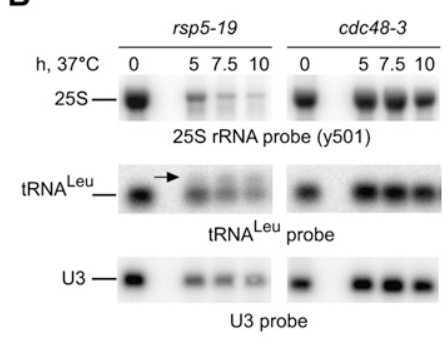

C

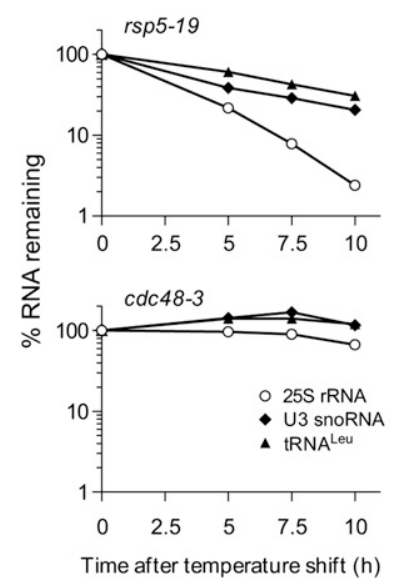

D

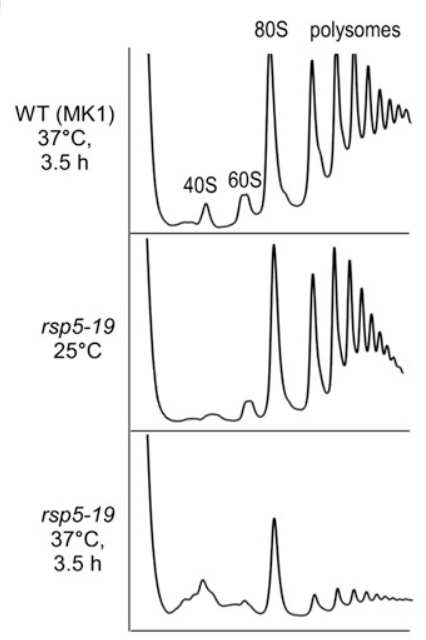

E

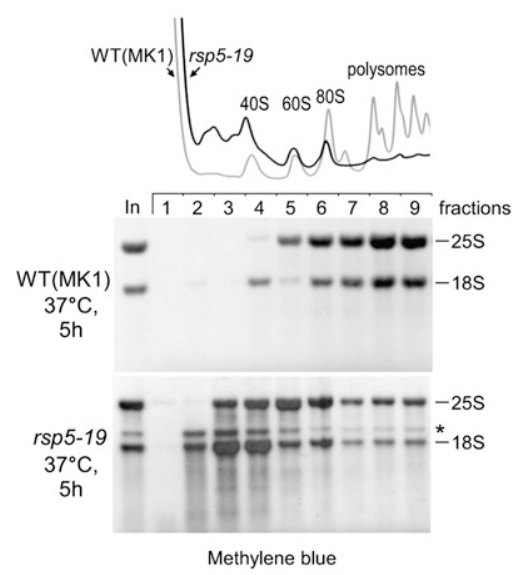

FIGURE 3. Mutations in RSP5 destabilize mature ribosomes. (A) Pulse-chase analysis of rRNA. Cells from $r s p 5-19$ and control $c d c 48$-3 strains were grown on YPDA to mid-log phase at $25^{\circ} \mathrm{C}$, labeled with $\left[{ }^{3} \mathrm{H}\right]$ uracil in SC-ura for $10 \mathrm{~min}$, washed, resuspended in YPDA, and further incubated at $37^{\circ} \mathrm{C}$. RNA was isolated from $5 \times 10^{6}$ cells at $5,7.5$, and $10 \mathrm{~h}$ after the labeling, separated by formaldehyde-agarose gel electrophoresis and blotted. $25 \mathrm{~S}$ and $18 \mathrm{~S}$ rRNAs labeled during the pulse were visualized by fluorography. Asterisk indicates the large $25 \mathrm{~S}$ rRNA degradation fragment detected in hybridizations (see Fig. 1A,B). (B) Cellular levels of different RNA types were analyzed by Northern hybridizations with probes against $25 \mathrm{~S}$ rRNA, tRNA ${ }^{\text {Leu }}$, and U3 snoRNA. Arrow indicates unprocessed tRNA precursors. $(C)$ PhosphorImager quantification of the relative levels of noncoding RNAs in Northern hybridizations shown in $B$. The signal at time zero (prior to temperature shift) is $100 \%$. $(D)$ Sucrose gradient sedimentation analysis of ribosomes extracted from the rsp5-19 and isogenic wild-type MK1 strains grown at the indicated temperatures. Mid-log cultures in YPDA at $25^{\circ} \mathrm{C}$ were shifted to $37^{\circ} \mathrm{C}$ for $3.5 \mathrm{~h}$ where indicated. Cell lysates were centrifuged through $15 \%-50 \%$ sucrose gradients and fractionated with the continuous measurement of absorbance at $254 \mathrm{~nm}$. (E) Sucrose gradient analysis of ribosomes from the $r s p 5-19$ and MK1 strains after $5 \mathrm{~h}$ at $37^{\circ} \mathrm{C}$. RNA was isolated from individual gradient fractions, separated on an agarose gel, transferred to a membrane, and stained with methylene blue. Positions of full-length 25S, 18S rRNA, and the $3^{\prime}$ degradation fragment of $25 \mathrm{~S}$ (asterisk) are indicated.

\section{Polysome analysis of $r s p 5$ mutant cells}

To better understand how inactivating Rsp5p function affected translating ribosomes, we separated cell lysates from the rsp5-19 and wild-type strains on a sucrose gradient. Consistent with a decrease in rRNA levels observed 
in hybridizations (Fig. 1A), the total level of ribosomes in rsp5-19 cells was greatly diminished after $3.5 \mathrm{~h}$ at $37^{\circ} \mathrm{C}$ (Fig. 3D). Notably, some ribosomes were still present in the form of polysomes, indicating that they were associated with intact mRNA. A gradient analysis of ribosomes in $r s p 5-19$ cells at $25^{\circ} \mathrm{C}$ or the wild-type MK1 strain at $37^{\circ} \mathrm{C}$ did not reveal any obvious abnormalities (Fig. 3D).

In addition to reduced peaks of polysomes and $80 \mathrm{~S}$ ribosomes in rsp5-19 cells, the top fractions of the gradient (corresponding to sedimentation coefficients $<40 S$ ) displayed unusual peaks (Fig. 3D, bottom), which further increased by $5 \mathrm{~h}$ at $37^{\circ} \mathrm{C}$ (Fig. 3E, top, fractions 2-4). Because free ribosomal subunits in yeast normally sediment at $40 \mathrm{~S}$ and $60 \mathrm{~S}$, and preribosomal particles are larger than mature subunits (Tschochner and Hurt 2003), accumulation of material in top gradient fractions might be due to RNA decay. Indeed, analysis of RNA isolated from the rsp519 gradient revealed an intensive smear of rRNA degradation products in the corresponding fractions (Fig. 3E, cf. RNA in fractions 2-4 in the wild-type and mutant cells). Strikingly, large quantities of full-length $18 \mathrm{~S}$ and $25 \mathrm{~S}$ rRNAs were also shifted to these fractions. The abnormally low sedimentation rate of the full-sized rRNAs suggests that a partial disassembly and/or unfolding of the ribosome structure may take place before the rRNA is degraded into smaller fragments. This result indicates that degradation of ribosomes in rsp5 cells is a complex process that involves a combination of nucleolytic events and structural alterations.

\section{Degradation of ribosomes in rsp5 cells does not require autophagy}

A ribosome-specific autophagy pathway, termed ribophagy, was recently reported (Kraft et al. 2008), and Rsp5p was proposed to act as a candidate ligase that carries out ubiquitination during this process (Kraft and Peter 2008). To determine whether rsp5 mutations might induce ribophagy or increase general autophagy, which is also known to direct cytoplasmic ribosomes to destruction in autophagic bodies (Takeshige et al. 1992), we introduced deletions of key autophagy genes into the $r s p 5-19$ strain: ATG7, essential for autophagosome formation (Suzuki and Ohsumi 2007); $A T G 19$, specific for an alternate cytoplasm-to-vacuole pathway (Yorimitsu and Klionsky 2005); UBP3, implicated in ribophagy (Kraft et al. 2008); and the vacuolar peptidase gene PEP4 (Rupp and Wolf 1995). To monitor autophagy, levels of a stable GFP fragment derived by cleavage of the marker protein GFP-Atg8p (Cheong and Klionsky 2008) were assessed by Western blotting.

As shown in Figure 4A, deletions of the autophagyrelated genes did not suppress rRNA degradation caused by the rsp5-19 mutation. Additionally, analysis of GFP-Atg8p showed that autophagy was not significantly induced in these cells, with the exception of the $u b p 3 \Delta$ strain (Fig. 4A, bottom). The low autophagy level was not unexpected, as

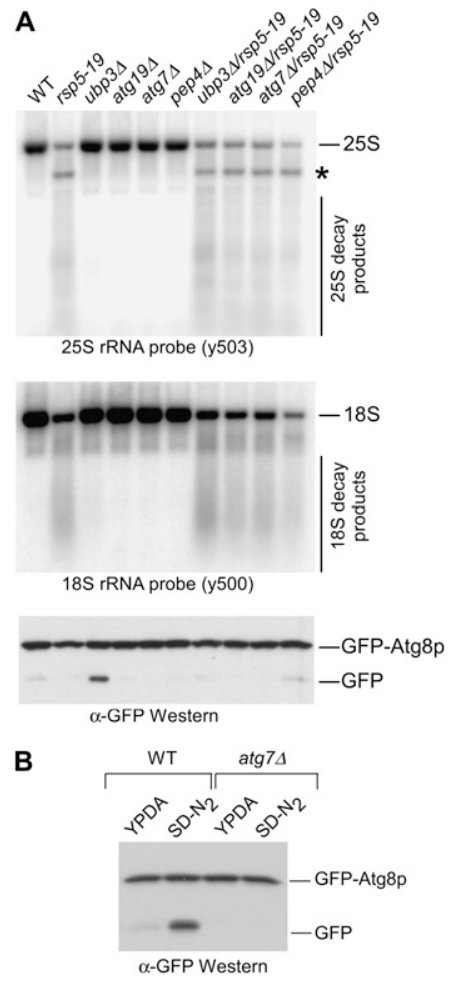

FIGURE 4. Ribosome degradation in rsp5-19 cells does not require autophagy. (A) The indicated yeast strains were transformed with a plasmid expressing the fusion marker protein GFP-Atg8p. Cells cultured in minimal selective medium were diluted with YPDA, grown at $25^{\circ} \mathrm{C}$ for $2 \mathrm{~h}$ to $\mathrm{OD}_{600} \sim 0.3$, and shifted to $37^{\circ} \mathrm{C}$ for $5 \mathrm{~h}$. RNA extracted from $10^{7}$ cells was analyzed by Northern hybridizations. Asterisk indicates the 3' degradation fragment of 25S rRNA (see Fig. 1B). To monitor autophagy, protein lysates from the same cultures were normalized by protein content and analyzed by immunoblotting to detect GFP cleaved off from GFP-Atg8p (bottom). (B) Autophagy is induced in the MK1 strain (WT) during nitrogen starvation and suppressed by atg7 $\Delta$ deletion. Cells were incubated in SD-N $\mathrm{N}_{2}$ medium lacking ammonium sulfate, Arg, His, and Lys for $4 \mathrm{~h}$. Induction of autophagy leads to accumulation of a stable GFP fragment of GFPAtg8p.

we cultured these cells in rich YPDA medium. The parental strain MK1 was not autophagy deficient, because cleavage of the autophagy marker GFP-Atg8p was readily observed after shifting these cells to nitrogen-free medium, and this cleavage was suppressed by the atg $7 \Delta$ mutation (Fig. 4B).

\section{Implications for understanding the cellular functions of Rsp5p and ribosome stability}

Taken together, our findings indicate that in the absence of a functional Rsp5p, cytoplasmic ribosomes in yeast cells can become unstable and suffer extensive degradation. The importance of Rsp5p for ribosome stability is supported by the similarity in rRNA degradation patterns observed in strains carrying different $t$ s alleles of RSP5 (Fig. 2A,B) and complementation of this phenotype by expression of the wild-type Rsp5p (Fig. 2C). The ribosome degradation 
caused by defective Rsp5p function was especially pronounced in cells maintained in rich medium and was not affected by deletion of key autophagy factors (Fig. 4). Although these results do not exclude a separate role that Rsp5p might play in ribophagy after prolonged nutrient restriction as proposed earlier (Kraft and Peter 2008), the breakdown of cellular ribosomes triggered by $r s p 5$ mutations in rich medium clearly utilizes a different mechanism.

The most intriguing question raised by these findings is what processes affected by a lack of Rsp5p function could lead to ribosome breakdown. Because other noncoding RNAs are destabilized in $r s p 5$ mutant cells, albeit to a lower extent than rRNA (Fig. 3B,C), one possibility may be that Rsp5p is required for the proper regulation of RNase activities in a cell, and that a loss of Rsp5p-mediated controls promotes an indiscriminate attack by RNases on a variety of cytoplasmic RNAs. Our preliminary data indeed point to the participation of broad-specificity nucleases in the RNA degradation in rsp5 mutant cells (N Shcherbik and D Pestov, in prep.). Other observations, such as the accumulation of a discrete large fragment of $25 \mathrm{~S}$ rRNA (Fig. $1 \mathrm{~A}, \mathrm{~B})$ and the decrease in sedimentation properties of ribosomal subunits prior to their degradation (Fig. 3E) argue that the role of Rsp5p is more complex, and that structural changes and partial disassembly of ribosomes may precede the eventual fragmentation of rRNA.

Ribosome turnover is usually assumed to occur under stress conditions, particularly upon starvation, when recycling of ribosome components might provide additional nutrients for the cell (Johnston et al. 1977; Kraft et al. 2008; Zundel et al. 2009). However, rich nutrient conditions present a problem of a different kind: Metabolically active cells need to have mechanisms that ensure that ribosomes remain intact, which includes prevention of damage to rRNA and other noncoding RNAs by cellular RNases (Deutscher 2003). In this study, our results suggest an important role for Rsp5p in controlling processes that influence the stability of the RNA-based translation machinery in yeast cells growing in rich media. A loss of ribosome integrity is likely to affect translational control of gene expression, decrease the overall protein synthesis capacity, and impair the ability of the cell to repair damage, all of which could contribute to other phenotypes associated with mutations in the RSP5 gene.

\section{MATERIALS AND METHODS}

\section{Yeast strains, plasmids, media, and antibodies}

Yeast strains and plasmids used in this study are listed in Supplemental Tables S1 and S2. We used standard recipes for YPDA ( $1 \%$ yeast extract, $2 \%$ peptone, $2 \%$ dextrose, $10 \mathrm{mg} / \mathrm{L}$ adenine) and synthetic minimal media. For autophagy assays, pep $4 \Delta$ and rsp5-19/pep4s cells were cultured in the presence of $0.1 \mathrm{mM}$ PMSF (Kraft et al. 2008). The anti-GFP antibody 7.1/13.1 was from Roche Biochemicals.

\section{rRNA analysis}

Yeast RNA was isolated by the acid phenol method (Schmitt et al. 1990). rRNA was separated on $1 \%-1.2 \%$ agarose gels containing $1.3 \%$ formaldehyde for Northern blotting and detected using ${ }^{32} \mathrm{P}$ labeled oligonucleotide probes (Supplemental Table S3) as described (Pestov et al. 2008). Hybridizations were analyzed using a Typhoon 9200 PhosphorImager and ImageQuant software (GE Biosciences).

For metabolic labeling of rRNA, cells from a $50 \mathrm{~mL}$ culture grown in YPDA to $\mathrm{OD}_{600} 0.4-0.6$ were collected by centrifugation, washed, and resuspended in $1 \mathrm{~mL}$ of prewarmed SD medium lacking uracil. Labeling was with $70 \mu \mathrm{Ci} / \mathrm{mL}\left[5,6-{ }^{3} \mathrm{H}\right]$ uracil (Perkin Elmer) for $10 \mathrm{~min}$ at $30^{\circ} \mathrm{C}$. Cells were then pelleted, washed with YPDA, resuspended in $50 \mathrm{~mL}$ of YPDA, and transferred to $37^{\circ} \mathrm{C}$, which arrested their proliferation owing to the presence of temperature-sensitive $r s p 5$ and $c d c 48$ alleles. Labeled RNA was separated on a formaldehyde-agarose gel, blotted, and detected by fluorography as described (Pestov et al. 2008).

\section{Fluorescent in situ hybridization}

Analysis of the intracellular rRNA localization was performed as described previously (Amberg et al. 1992), with the following modifications. The methanol/acetone dehydration step was omitted; $0.4 \mathrm{U} / \mu \mathrm{L}$ of RNase inhibitor (Fermentas) was added to the prehybridization and hybridization solutions. Hybridizations were performed in buffer containing 50\% formamide and $0.2 \mu \mathrm{M} \mathrm{Cy} 3-$ labebed oligonucleotide probes (Supplemental Table S3) at $37^{\circ} \mathrm{C}$ overnight. After hybridization, cells were washed with $2 \times \mathrm{SSC}$ for $30 \mathrm{~min}$ at $37^{\circ} \mathrm{C}, 1 \times \mathrm{SSC}$ for $30 \mathrm{~min}$ at $37^{\circ} \mathrm{C}$, and $0.5 \times \mathrm{SSC}$ for 15 min at room temperature. Slides were mounted in the Vectashield medium (Vector) containing DAPI and examined with a Zeiss Apotome microscope.

\section{Sucrose gradients}

Polysomes were prepared essentially as described previously (Sagliocco et al. 1996). Cells were treated with $100 \mu \mathrm{g} / \mathrm{mL}$ cycloheximide $10 \mathrm{~min}$ prior to harvesting, pelleted by centrifugation, washed twice in ice-cold lysis buffer $(100 \mathrm{mM} \mathrm{NaCl}, 3 \mathrm{mM} \mathrm{MgCl}$, $10 \mathrm{mM}$ Tris- $\mathrm{HCl}$ at $\mathrm{pH} 7.4,100 \mu \mathrm{g} / \mathrm{mL}$ of cycloheximide, and 200 $\mu \mathrm{g} / \mathrm{mL}$ heparin), resuspended in lysis buffer, and broken open by vortexing with glass beads at $4^{\circ} \mathrm{C}$. An aliquot corresponding to 50 $\mathrm{OD}_{260}$ of the clarified lysate was loaded onto $15 \%-50 \%(\mathrm{w} / \mathrm{v})$ sucrose gradients prepared in $70 \mathrm{mM} \mathrm{NH}_{4} \mathrm{Cl}, 4 \mathrm{mM} \mathrm{MgCl}_{2}$, and $10 \mathrm{mM}$ Tris- $\mathrm{HCl}$ ( $\mathrm{pH} 7.4)$. Gradients were centrifuged at $188,000 \mathrm{~g}$ at $4^{\circ} \mathrm{C}$ for $4.5 \mathrm{~h}$ (Beckman SW41Ti rotor, 36,000 rpm) and fractionated using a Beckman fraction recovery system connected to a EM-1 UV monitor (Bio-Rad).

\section{SUPPLEMENTAL MATERIAL}

Supplemental material is available for this article.

\section{ACKNOWLEDGMENTS}

We thank Tereza Żoładek for providing rsp5 strains and Tom Rapoport for $\mathrm{W} 303 \alpha$ and $c d c 48-3$ strains. We are grateful to Katrina Cooper, Jelena Jakovljevic, Terri Kinzy, Michael Law, Randy Strich, and Minshi Wang for valuable technical advice and 
constructive comments on the manuscript. This work was supported by the American Heart Association grant 09SDG2140065 to N.S. The Foundation of UMDNJ grant PC38-10 and the NIH grant GM074091 provided support to D.G.P.

Received December 23, 2010; accepted May 5, 2011.

\section{REFERENCES}

Amberg DC, Goldstein AL, Cole CN. 1992. Isolation and characterization of RAT1: An essential gene of Saccharomyces cerevisiae required for the efficient nucleocytoplasmic trafficking of mRNA. Genes Dev 6: 1173-1189.

Basturea GN, Zundel MA, Deutscher MP. 2011. Degradation of ribosomal RNA during starvation: Comparison to quality control during steady-state growth and a role for RNase PH. RNA 17: 338345.

Belgareh-Touzé N, Léon S, Erpapazoglou Z, Stawiecka-Mirota M, Urban-Grimal D, Haguenauer-Tsapis R. 2008. Versatile role of the yeast ubiquitin ligase Rsp5p in intracellular trafficking. Biochem Soc Trans 36: 791-796.

Chen ZJ, Sun LJ. 2009. Nonproteolytic functions of ubiquitin in cell signaling. Mol Cell 33: 275-286.

Cheong H, Klionsky DJ. 2008. Biochemical methods to monitor autophagy-related processes in yeast. Methods Enzymol 451: 1-26.

Cole SE, LaRiviere FJ, Merrikh CN, Moore MJ. 2009. A convergence of rRNA and mRNA quality control pathways revealed by mechanistic analysis of nonfunctional rRNA decay. Mol Cell 34: 440-450.

Deutscher MP. 2003. Degradation of stable RNA in bacteria. J Biol Chem 278: 45041-45044.

Dez C, Houseley J, Tollervey D. 2006. Surveillance of nuclearrestricted pre-ribosomes within a subnucleolar region of Saccharomyces cerevisiae. EMBO J 25: 1534-1546.

Fujii K, Kitabatake M, Sakata T, Miyata A, Ohno M. 2009. A role for ubiquitin in the clearance of nonfunctional rRNAs. Genes Dev 23: 963-974.

Haitani Y, Takagi H. 2008. Rsp5 is required for the nuclear export of mRNA of HSF1 and MSN2/4 under stress conditions in Saccharomyces cerevisiae. Genes Cells 13: 105-116.

Hicke L. 2001. Protein regulation by monoubiquitin. Nat Rev Mol Cell Biol 2: 195-201.

Hochstrasser M. 1996. Ubiquitin-dependent protein degradation. Annu Rev Genet 30: 405-439.

Huibregtse JM, Scheffner M, Beaudenon S, Howley PM. 1995. A family of proteins structurally and functionally related to the E6AP ubiquitin-protein ligase. Proc Natl Acad Sci 92: 2563-2567.

Johnston GC, Singer RA, McFarlane S. 1977. Growth and cell division during nitrogen starvation of the yeast Saccharomyces cerevisiae. J Bacteriol 132: 723-730.

Jorgensen P, Rupes I, Sharom JR, Schneper L, Broach JR, Tyers M. 2004. A dynamic transcriptional network communicates growth potential to ribosome synthesis and critical cell size. Genes Dev 18: 2491-2505.

Ju Q, Warner JR. 1994. Ribosome synthesis during the growth cycle of Saccharomyces cerevisiae. Yeast 10: 151-157.

Kaliszewski P, Żoładek T. 2008. The role of Rsp5 ubiquitin ligase in regulation of diverse processes in yeast cells. Acta Biochim Pol 55: 649-662.

Kaliszewski P, Ferreira T, Gajewska B, Szkopinska A, Berges T, Żołądek T. 2006. Enhanced levels of Pislp (phosphatidylinositol synthase) improve the growth of Saccharomyces cerevisiae cells deficient in Rsp5 ubiquitin ligase. Biochem J 395: 173-181.

Kief DR, Warner JR. 1981. Coordinate control of syntheses of ribosomal ribonucleic acid and ribosomal proteins during nutritional shift-up in Saccharomyces cerevisiae. Mol Cell Biol 1: 1007-1015.

Kos M, Tollervey D. 2010. Yeast pre-rRNA processing and modification occur cotranscriptionally. Mol Cell 37: 809-820.
Kraft C, Peter M. 2008. Is the Rsp5 ubiquitin ligase involved in the regulation of ribophagy? Autophagy 4: 838-840.

Kraft C, Deplazes A, Sohrmann M, Peter M. 2008. Mature ribosomes are selectively degraded upon starvation by an autophagy pathway requiring the Ubp3p/Bre5p ubiquitin protease. Nat Cell Biol 10: 602-610.

Krsmanović T, Kölling R. 2004. The HECT E3 ubiquitin ligase Rsp5 is important for ubiquitin homeostasis in yeast. FEBS Lett 577: 215-219.

Kwapisz M, Chołbiński P, Hopper AK, Rousset J, Żołądek T. 2005. Rsp5 ubiquitin ligase modulates translation accuracy in yeast Saccharomyces cerevisiae. RNA 11: 1710-1718.

Lafontaine DLJ. 2010. A 'garbage can' for ribosomes: how eukaryotes degrade their ribosomes. Trends Biochem Sci 35: 267-277.

LaRiviere FJ, Cole SE, Ferullo DJ, Moore MJ. 2006. A late-acting quality control process for mature eukaryotic rRNAs. Mol Cell 24: 619-626.

Mroczek S, Kufel J. 2008. Apoptotic signals induce specific degradation of ribosomal RNA in yeast. Nucleic Acids Res 36: 2874-2888.

Neumann S, Petfalski E, Brügger B, Grosshans H, Wieland F, Tollervey D, Hurt E. 2003. Formation and nuclear export of tRNA, rRNA and mRNA is regulated by the ubiquitin ligase Rsp5p. EMBO Rep 4: $1156-1162$.

Pestov DG, Lapik YR, Lau LF. 2008. Assays for ribosomal RNA processing and ribosome assembly. Curr Protoc Cell Biol doi: 10.1002/0471143030.cb2211s39.

Rodriguez MS, Gwizdek C, Haguenauer-Tsapis R, Dargemont C. 2003. The HECT ubiquitin ligase Rsp5p is required for proper nuclear export of mRNA in Saccharomyces cerevisiae. Traffic 4: 566-575.

Roos-Mattjus P, Sistonen L. 2004. The ubiquitin-proteasome pathway. Ann Med 36: 285-295.

Rotin D, Kumar S. 2009. Physiological functions of the HECT family of ubiquitin ligases. Nat Rev Mol Cell Biol 10: 398-409.

Rupp S, Wolf DH. 1995. Biogenesis of the yeast vacuole (lysosome). The use of active-site mutants of proteinase yscA to determine the necessity of the enzyme for vacuolar proteinase maturation and proteinase yscB stability. Eur J Biochem 231: 115-125.

Sagliocco FA, Moore PA, Brown AJ. 1996. Polysome analysis. Methods Mol Biol 53: 297-311.

Schmitt ME, Brown TA, Trumpower BL. 1990. A rapid and simple method for preparation of RNA from Saccharomyces cerevisiae. Nucleic Acids Res 18: 3091-3092.

Suzuki K, Ohsumi Y. 2007. Molecular machinery of autophagosome formation in yeast, Saccharomyces cerevisiae. FEBS Lett 581: 2156-2161.

Takeshige K, Baba M, Tsuboi S, Noda T, Ohsumi Y. 1992. Autophagy in yeast demonstrated with proteinase-deficient mutants and conditions for its induction. J Cell Biol 119: 301-311.

Thompson SJ, Loftus LT, Ashley MD, Meller R. 2008. Ubiquitinproteasome system as a modulator of cell fate. Curr Opin Pharmacol 8: 90-95.

Tschochner H, Hurt E. 2003. Pre-ribosomes on the road from the nucleolus to the cytoplasm. Trends Cell Biol 13: 255-263.

Vanacova S, Stefl R. 2007. The exosome and RNA quality control in the nucleus. EMBO Rep 8: 651-657.

Wang G, Yang J, Huibregtse JM. 1999. Functional domains of the Rsp5 ubiquitin-protein ligase. Mol Cell Biol 19: 342-352.

Warner JR. 1999. The economics of ribosome biosynthesis in yeast. Trends Biochem Sci 24: 437-440.

Weber MJ. 1972. Ribosomal RNA turnover in contact inhibited cells. Nat New Biol 235: 58-61.

Weissman AM. 2001. Themes and variations on ubiquitylation. Nat Rev Mol Cell Biol 2: 169-178.

Yorimitsu T, Klionsky DJ. 2005. Atg11 links cargo to the vesicleforming machinery in the cytoplasm to vacuole targeting pathway. Mol Biol Cell 16: 1593-1605.

Yuan D, Shen V. 1975. Stability of ribosomal and transfer ribonucleic acid in Escherichia coli $\mathrm{B} / \mathrm{r}$ after treatment with ethylenedinitrilotetraacetic acid and rifampicin. J Bacteriol 122: 425-432.

Zundel MA, Basturea GN, Deutscher MP. 2009. Initiation of ribosome degradation during starvation in Escherichia coli. RNA 15: 977-983. 

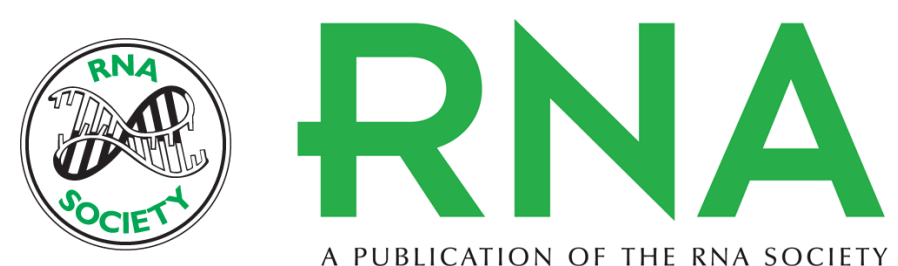

A PUBLICATION OF THE RNA SOCIETY

\section{The ubiquitin ligase Rsp5 is required for ribosome stability in Saccharomyces cerevisiae}

Natalia Shcherbik and Dimitri G. Pestov

RNA 2011 17: 1422-1428 originally published online June 10, 2011

Access the most recent version at doi:10.1261/rna.2615311

\section{Supplemental http://rnajournal.cshlp.org/content/suppl/2011/06/01/rna.2615311.DC1 \\ Material}

References This article cites 46 articles, 17 of which can be accessed free at: http://rnajournal.cshlp.org/content/17/8/1422.full.html\#ref-list-1

\section{License}

Email Alerting Receive free email alerts when new articles cite this article - sign up in the box at the Service top right corner of the article or click here. 